\title{
Evaluation of the Process Governing Groundwater Suitability for Irrigation at 0ju and its Adjourning Area, Benue State, Nigeria. using Hydrochemical Approach
}

\author{
M 0 Eyankware ${ }^{1 *}$, C Ogwah ${ }^{1}$ and A 0 I Selemo ${ }^{2}$ \\ ${ }^{1}$ Department of Geology, Ebonyi State University, Nigeria \\ ${ }^{2}$ Department of Geosciences, Federal University of Technology, Nigeria
}

Submission: November 29, 2018; Published: December 20, 2018

*Corresponding author: M O Eyankware, Department of Geology, Faculty of Sciences, Ebonyi State University, Abakaliki, Ebonyi State, Nigeria

\begin{abstract}
Groundwater from shallow wells were evaluated for irrigation purpose, within Ukwuoku Hills, Oju local government area of Benue State, Nigeria. The study area lies within Asu River Group of the Lower Benue Trough, southern Nigeria. Physicochemical parameters analyzed include physical parameters such as; $\mathrm{pH}$, total dissolved solid and electrical conductivity and chemical parameters such as; major cation and anion. The above-mentioned parameters were analyzed using America Public Health Association standard method. Results from the study showed that $\mathrm{pH}$ falls within slightly basic to acidic, electrical conductivity ranges from 127 to $760 \mu \mathrm{S} / \mathrm{cm}$, Soluble Sodium Percentage ranges from 1.53 to 43.78 , Sodium Percentage ranges from 1.55 to 77.8 \% Kelly Ratio ranges from 0.01 to 0.77 , Magnesium Absorption Ratio ranges from 0.00 to 61.98 and total hardness Total Hardness ranges from 72.00 to 425.5 within the study area. The above listed parameters were below various permissible standard value for irrigation except for MAR at OJU/LBT/04, Na\% at OJU/LBT/09, 13 and 14, SAR at 01 and 04 and TH at 0JU/LBT/04 that were slightly above various permissible standard values. From Gibbs plot it was observed that rock dominance is the major factor that influences groundwater except for few sampling points were precipitation dominance was observed to have influence on groundwater within the study area.
\end{abstract}

Keywords: Groundwater; Electrical conductivity; Suitability; Lower benue trough and shallow

\section{Introduction}

Groundwater can be regarded as of the one most important natural resource, large percentage of it exists within the study area at shallow depth, and found in fractures at shallow depth, that ranges from 10 and 40m [1]. It is largely used for domestic, agricultural and industrial purpose [2]. Further stated that depth to the water-table below the surface varies from place to place but is generally less than $20 \mathrm{~m}$. Borehole yields can be highly variable, and in many locations, it can be difficult to find sustainable water supplies. Groundwater within the study area is extensively exploited by hand-dug wells and manual borehole. But area around the Ukwokwu Hills tends to be more fractured and have high groundwater potentials compared to other parts of the study area, due to tectonic activities that occurred within Ukwokwu Hills that lead to these fractures. With the limited groundwater resources that is available for use within the Asu River Group of Lower Benue Trough, anthropogenic activities have also posed treat to usage of water for domestic, industrial and agricultural use [2-5]. Most human waste are channeled into surface water, while the other infiltrate into groundwater thereby altering the quality for various use. Generally, groundwater is considered less prone to pollution compare to surface water. It is the only source of water available all year round as most of the surface water dry up during the dry season [6]. Demand for groundwater has been on high side for domestic, agricultural and industrial use globally [7-9]. Its availability for irrigation has contributed to increase in crop productivity in country like Bangladesh [7]. But the reverse is the case in Nigeria as most research on groundwater are channeled towards its quality for drinking and domestic use. [6,10] evaluated groundwater quality for domestic use within the Lower Benue Trough. Hence the need for evaluation of groundwater for irrigation. As for Irrigation water emphasis is placed on the physicochemical attribute of water and on rare situation are other factors considered important [4]. 


\section{Location and accessibility}

The study area is in Oju, local government area of Benue Sate. Geographically the study covers between latitude $6^{0} 50^{\prime} \mathrm{N}$ $6^{0} 55^{\prime} \mathrm{N}$ and longitude $8^{0} 22^{\prime} \mathrm{E}-8^{0} 27^{\prime} \mathrm{E}$. The area is accessible by
Otukpo/Oju road, with some other minor road Nkache, Ameke and others as shown in Figure 1. The area lies within the Federal Survey of Nigeria topographic sheet 289 of $(1: 100,000)$ Ejekwe sheet.

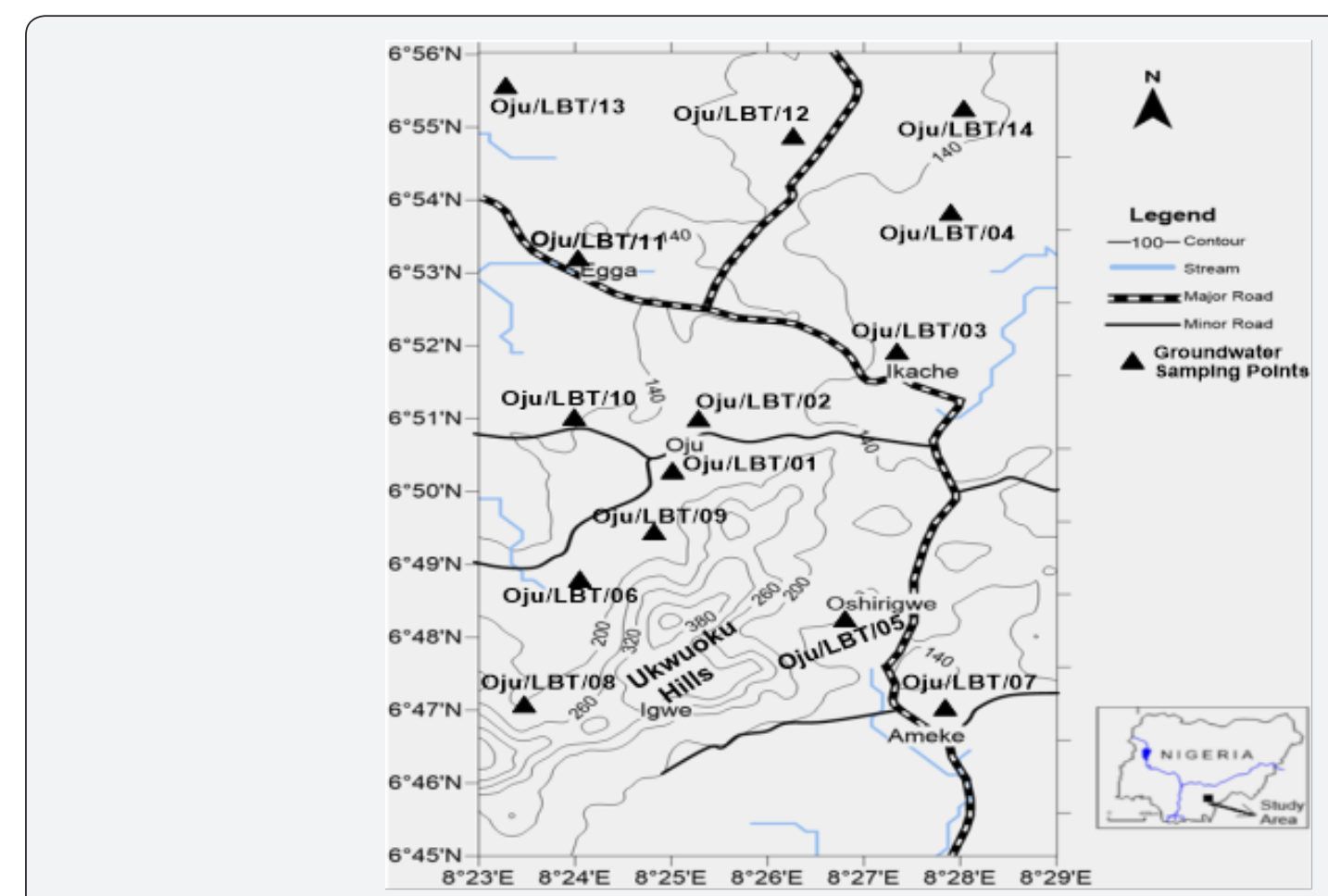

Figure 1: Topography Showing Water Sampling Map of the Study Area.

\section{Vegetation and climate}

[11] stated that the climate of Nigeria is classified into two major seasons occur within the area namely: dry and rainy season. The dry season prevails from November to March, but between December and early month of February and the Sahara anticyclone from the northern hemisphere causes dry and dust laden air mass blowing from across the desert through parts of the northern Nigeria. The area is characterized by relatively warm temperature days of $27^{\circ} \mathrm{C}$ to $32^{\circ} \mathrm{C}$ and moderately cool nights of $17^{\circ} \mathrm{C}$ to $28^{\circ} \mathrm{C}$. The rainy season start from April to October with an august break or little period of no rain. The rains occur as violet downpours accomplished by thunderstorms, heavily flooding, soil and gully erosion and fast groundwater infiltration within the study area and experience high relative humidity of about $65 \%$ to $80 \%$ with it peak of rain season when there is medium to low sunshine hours and low evaporation. Drainage and topography are the two main factors known to control the vegetation of any locality and that of the study area is not excluded. Sparse vegetation may be found on the Plateau while luxuriant vegetation occurs in the plains. The highland areas within the Ukwokwu Hills have grasses and few shrubs, while the lowland areas and valleys consist of few grasses. [11] stated that the study area lies within the humid tropical rainforest belt of Nigeria with partially deforested northern parts turning into derived Savanna grassland.

\section{Hydrogeology of the study area}

Hydrochemistry of surface and groundwater is controlled by the rocks and sediments through which these waters flow through [12,13]. Generally, the movement and storage of groundwater within the area is controlled by three major factors namely; lithology, thickness and structure of rock formation (predominantly shales of the Asu River Group). Shale is an aquiclude and does not permit reasonable quantity of water, especially when fresh and unweathered. There are, however, intercalations of clays and sand clays which have led to artesian conditions in the study area. In the same vein, groundwater in the areas generally exists in fractured zones within the Asu River Group, sandstone and limestone layers or members, weathered zones, and bedrock interfaces with shale group [14]. The Asu River facies are poor in groundwater potentials.

\section{Regional tectonic setting}

The Benue right has been referred to a Benue valley [15]; Benue depression [16]; Benue Trough [17] and Benue aulacogen. It is known to be an intra continental rift basin which is a part of the Gulf of Guinea, South Atlantic, Benue triple junction with its centre occupied by the Niger Delta. Geographically it is subdivided into the Upper, Middle and Lower parts. The basin is filled mainly by Pre-Santonian (late Aptian to Coniacian) sedimentary rocks which are believed to have undergone 
regional burial metamorphism at the anchizonal to lower greenschist grade [18,19]. [20,21] and other researcher/ scholar has carried out research on the Benue Trough sedimentary till and its mainly focused on the told characterize sedimentary environments and relative age- detains using final assemblages. Emphasis is on Lower Benue Trough because the study area lies within the area.

\section{Geology of the study area}

The Lower Benue Trough is subdivided into the Asu River Group, Eze Aku Formation and the Awgu Formation based on time and age as shown in Table 1. Asu River Group: This stratigraphic unit was first named after the Shell D' Arcy area geologist and it was referred to formation the oldest sedimentary unit in the Western Cross River plain [22]. This group contains the initial cretaceous trangessive sediment in the sub-basin [23]. It has been recognized in both outcrops and subsurface in Abakaliki, Ogoja and Okposi as states by the [23]. It was generally described as the Lower shale and Cross River - Benue Shale by [24], [20] referred to it as Asu River Series while [25] assigned it as the Asu River Formation. The Asu River
Group uplift displays the most serve deformation in a relatively narrow slip $(20 \mathrm{~km}$ ) wide running NE-SW for over $200 \mathrm{~km}$. The overall structure sediment as the core. Beds of the Albian Asu River Group facies went through two deformational (folding) phase- a less intense one in the Cenomanian [26,27] and a more intense phase in Santonian. This account for the presence of on unconformity within the sedimentary succession of the Lower Benue Trough the sediment between of the Asu River Group facies and the Eze Aku Group facies. The Asu River Group comprises of olive brown or bluish grey shale and sandy shale, fine-grained micaeous sandstone and miceaous mudstone with thin limestone around the Abakaliki area [20]. [22] stated that folding episode affected mainly the sediment of the Asu River Group around the Ukwokwu Hill (Workum Hills). He further stated that the folding affected the shale and that the Ukwokwu Hills display particularly well-developed cleavage related to low grade metamorphosed resulting indurated slates. The folds form sets were parallel axis resulting mainly from a simple shortening by flexure due to horizontal compression. Both flexural and flattening resulted from the same compressive process but with a combined effect of dragging due to concomitant sharing.

Table 1: Lithostratigraphic framework for the Early Cretaceous-Tertiary period in southeastern Nigeria [28].

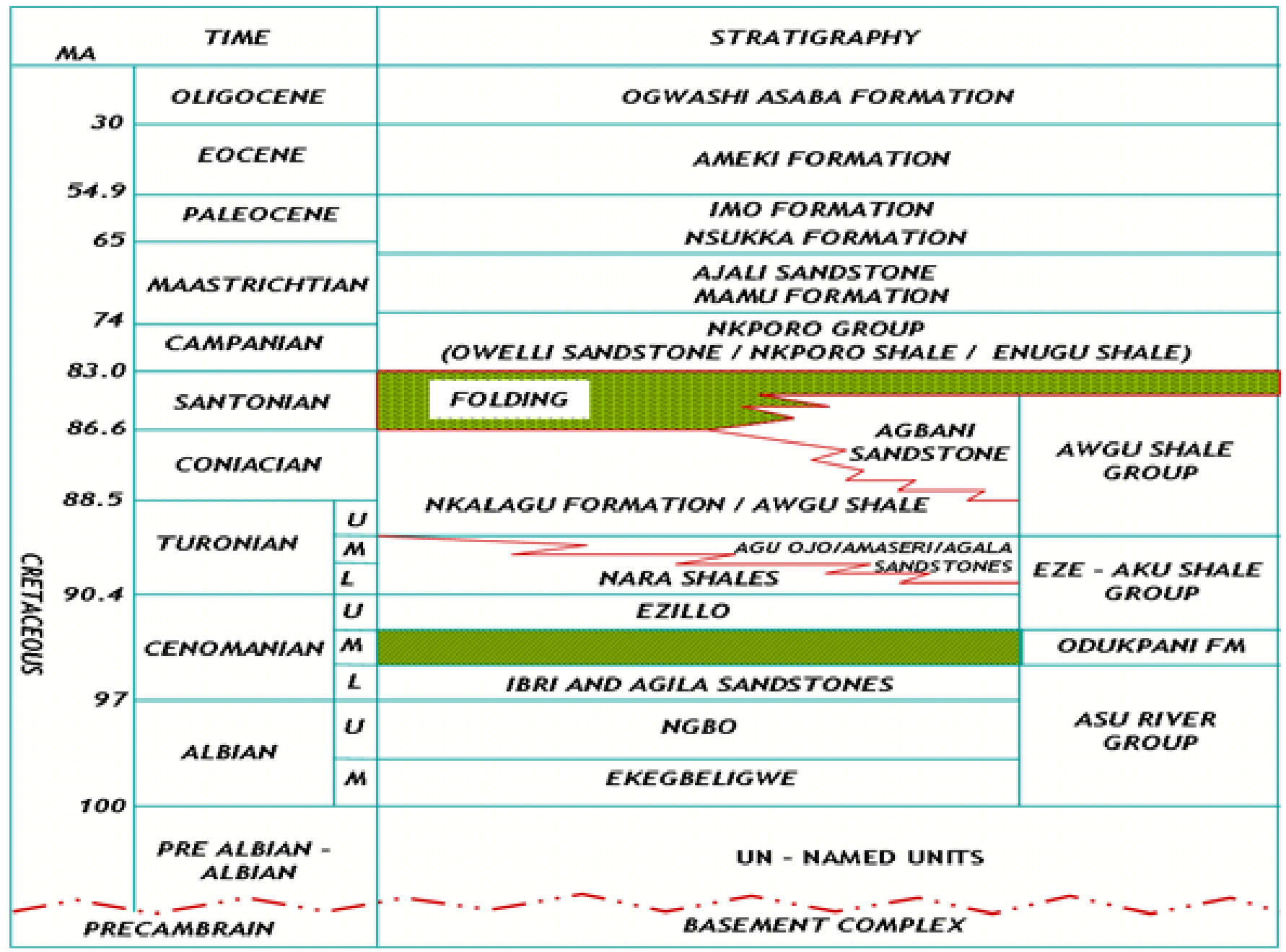




\section{Sampling and Laboratory Analysis}

\section{Laboratory method}

Systematic groundwater approach was used in groundwater sampling and various physicochemical parameters were analyzed following [29] see Table 2. And their result presented in Table 3. Fourteen groundwater samples were collected at various site in $0 \mathrm{ju}$, Benue state Nigeria to get the baseline information regarding the quality see Figure $1 \& 2$.

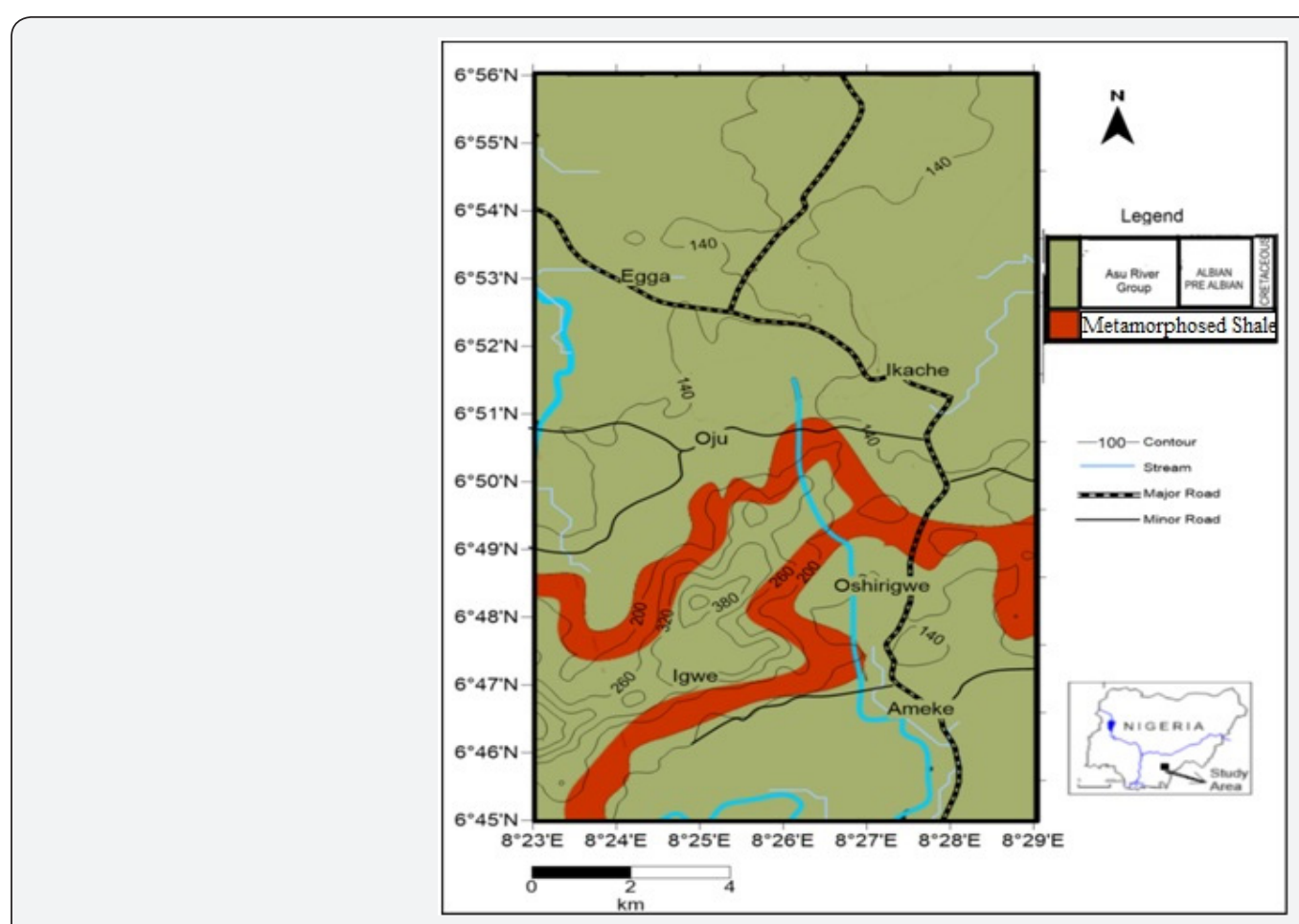

Figure 2: Geology map of the study area.

Table 2: Method used to analyze physicochemical parameters.

\begin{tabular}{|c|c|c|}
\hline S/No & Parameters & Analytical Method \\
\hline 1 & $\mathrm{pH}$ & $\begin{array}{l}\text { pH meter Hach sensION + PH1 portable pH meter and Hach sensION + } 5050 \text { T Portable Combination } \\
\text { pH Electrode }\end{array}$ \\
\hline 2 & Electrical Conductivity (EC) & HACH Conductivity \\
\hline 3 & Total dissolved solids (TDS) & TDS meters (model HQ14D53000000, USA). \\
\hline 4 & Magnesium $\left(\mathrm{Mg}^{2+}\right)$ & EDTA titrimetric method \\
\hline 5 & Calcium $\left(\mathrm{Ca}^{2+}\right)$ & Titrimetric method \\
\hline 6 & Chloride $\left(\mathrm{Cl}^{-}\right)$ & Titrimetric method \\
\hline 7 & Nitrate $\left(\mathrm{NO}^{3-}\right)$ & Ion-selective electrode (Orion 4 star) \\
\hline 8 & Sulphate $\left(\mathrm{SO}_{4}{ }^{2-}\right)$ & Turbidimetric method using a UV-Vis spectrometer \\
\hline 9 & Potassium $\left(\mathrm{K}^{+}\right)$ & Jenway clinical flame photometer (PFP7 model) \\
\hline 10 & Sodium $\left(\mathrm{Na}^{+}\right)$ & Jenway clinical flame photometer (PFP7 model) \\
\hline 11 & Bicarbonate $\left(\mathrm{HCO}_{3}^{-}\right)$ & Titrimetric method \\
\hline
\end{tabular}

Table 3: Result of Physical and Chemical Parameters.

\begin{tabular}{|c|c|c|c|c|c|c|c|c|c|c|c|}
\hline Sample Code & $\begin{array}{c}\mathrm{EC}(\mu \mathrm{S} / \\
\mathrm{cm})\end{array}$ & pH & TDS & $\begin{array}{c}\mathrm{Cl}^{-} \\
(\mathrm{meq} / \mathrm{L})\end{array}$ & $\begin{array}{c}\mathrm{Ca}^{2+} \\
(\mathrm{meq} / \mathrm{L})\end{array}$ & $\begin{array}{c}\mathrm{Mg}^{2+} \\
(\mathrm{meq} / \mathrm{L})\end{array}$ & $\begin{array}{c}\mathrm{Na}^{+} \\
(\mathrm{meq} / \mathrm{L})\end{array}$ & $\begin{array}{c}\mathrm{NO}_{3}^{-} \\
(\mathrm{meq} / \mathrm{L})\end{array}$ & $\begin{array}{c}\mathrm{SO}_{4}^{2-} \\
(\mathrm{meq} / \mathrm{L})\end{array}$ & $\begin{array}{c}\mathrm{K}^{+} \\
(\mathrm{meq} / \mathrm{L})\end{array}$ & $\begin{array}{c}\mathrm{HCO}_{3}^{-} \\
(\mathrm{meq} / \mathrm{L})\end{array}$ \\
\hline Oju/LBT/01 & 727 & 6.6 & 473 & 0 & 3.41 & 1.64 & 1.18 & 0.03 & 0 & 0.03 & 0.08 \\
\hline Oju /LBT/02 & 531 & 6.8 & 167 & 0.02 & 3.2 & 1.07 & 1.66 & 0.04 & 0 & 0.05 & 0.1 \\
\hline Oju /LBT/03 & 590 & 6.6 & 294 & 0 & 4.5 & 0 & 0.07 & 0.02 & 0.21 & 0.04 & 0.14 \\
\hline Oju /LBT/04 & 760 & 6.7 & 372 & 0 & 3.44 & 5.61 & 2.01 & 0.04 & 0.02 & 0.09 & 0.03 \\
\hline Oju /LBT/05 & 670 & 7.4 & 355 & 0 & 2.92 & 0 & 1.13 & 0.03 & 0.04 & 0.03 & 0.29 \\
\hline
\end{tabular}




\section{International Journal of Environmental Sciences \& Natural Resources}

\begin{tabular}{|c|c|c|c|c|c|c|c|c|c|c|c|}
\hline Oju /LBT/06 & 318 & 7.7 & 199 & 0 & 2.61 & 1.45 & 0.48 & 0.03 & 0 & 0.02 & 0.01 \\
\hline Oju /LBT/07 & 430 & 6.6 & 277 & 0 & 2.11 & 0.68 & 0.96 & 0.04 & 0.04 & 0.17 & 0.18 \\
\hline Oju /LBT/08 & 404 & 6.8 & 283 & 0 & 0.91 & 1.97 & 0.61 & 0.05 & 0.08 & 0.05 & 0.4 \\
\hline Oju /LBT/09 & 314 & 6.7 & 225 & 0 & 1.89 & 2.21 & 2.33 & 0.03 & 0.02 & 0.04 & 0.13 \\
\hline Oju/LBT/10 & 362 & 6.5 & 199 & 0 & 2.93 & 1.89 & 0.45 & 0.04 & 0 & 0.07 & 0.22 \\
\hline Oju/LBT/11 & 253 & 6.7 & 95 & 1 & 1.34 & 0.1 & 0.99 & 0.08 & 0.05 & 0.02 & 0.39 \\
\hline Oju /LBT/12 & 146 & 6.9 & 74 & 1 & 0.56 & 1.04 & 0.75 & 0.05 & 0.11 & 0.06 & 0.35 \\
\hline Oju/LBT/13 & 254 & 7.2 & 101 & 0.42 & 2.17 & 0 & 1.69 & 0.02 & 0.1 & 0.08 & 0.22 \\
\hline Oju/LBT/14 & 127 & 6.7 & 92 & 1 & 1.46 & 0 & 0.88 & 0.05 & 0.23 & 0.03 & 0.09 \\
\hline Minimum & 127 & 6.5 & 74 & 0 & 0.56 & 0 & 0.07 & 0.02 & 0 & 0.02 & 0.01 \\
\hline Maximum & 760 & 7.7 & 473 & 1 & 4.5 & 5.61 & 2.33 & 0.08 & 0.23 & 0.17 & 0.4 \\
\hline Average & 423.31 & 6.88 & 234.56 & 0.27 & 2.4 & 1.45 & 1.09 & 0.04 & 0.07 & 0.06 & 0.19 \\
\hline
\end{tabular}

The accuracy of geochemical analysis was determined by calculating the ionic balance, which was within $(1: 1 \pm 0.01 \%)$ as plotted using Surfer. 10 software packages. Irrigation parameters were determined by calculating the relations below in (meq/L). The suitability of groundwater for irrigation was evaluated by comparing the water samples with various water quality standards for irrigation and calculated using Eqn 3 to 8.

\section{Analytical check / ionic balancing}

The correctness of the chemical results was assessed using the relationship between the anions and the cations in the analyzed samples as expressed in milliequivalent per litre. The equations according to [30-32] are represented as;

$$
\% \text { Parameters }=\frac{\text { Individual parameter }}{\text { Total parameter }} \times 100
$$

The above equation gave a cation-anion ratio of $1: 1 \pm 0.01$, which confirms that the geochemical analysis was accurate.

The cation-anion balance was also assessed using electrical neutrality equation which requires that the sum of positive ions must be equal to sum of negative ions in solution expressed in meq/L.

$$
\% \text { difference }\left(\frac{m e q}{L}\right)=\left(\frac{\sum \text { cations }-\sum \text { anions }}{\sum \text { cations }-\sum \text { anions }}\right) \times 100 \%
$$

\section{Irrigation parameters}

Soluble sodium percentage (SSP): As proposed by [33,34] ascertains the level of sodium in water used for irrigation.

$$
\mathrm{SSP}=\frac{\left(\mathrm{Na}^{+}+\mathrm{K}^{+}\right) \times 100}{\mathrm{Ca}^{2}+\mathrm{Mg}^{2+}+\mathrm{Na}^{+}+\mathrm{K}^{+}}
$$

Magnesium adsorption ratio (MAR): The suitability of magnesium ion in natural water is assessed using the above parameter [35]. The equation below is used to calculate MAR.

$$
M A R=\frac{M g^{2+} \times 100}{M g^{2+}+C a^{2+}}
$$

Sodium percentage ( $\mathbf{N a} \%)$ : The effect of high sodium in natural water is also studied using the equation below by $[36,37]$.

$$
\mathrm{Na} \%=\frac{\mathrm{Na}^{+} \times 100}{\mathrm{Ca}^{2+}+\mathrm{Mg}^{2+}}
$$

Sodium adsorption ratio (SAR): The concentration of sodium in relation to $\mathrm{Na}^{+}, \mathrm{Ca}^{2+}, \mathrm{Mg}^{2+}$ is assessed using the equation according to [33] to calculate SAR. Thus,

$$
S A R=\frac{N a^{+}}{\sqrt{\frac{C a^{2+}+M g^{2+}}{2}}}
$$

Kelly's ratio (KR): This parameter measures the concentration of $\mathrm{Na}^{+}$against the concentration of the alkaline earth metals $\left(\mathrm{Ca}^{2+}\right.$ and $\left.\mathrm{Mg}^{2+}\right)$. The equation by [38] is used to calculate KR.

$$
K R=\frac{\mathrm{Na}^{+}}{\mathrm{Ca}^{2+}+\mathrm{Mg}^{2+}}
$$

Total hardness (TH): The softness or hardness of water for irrigation is assessed using the relation by $[35,39]$. Thus,

$$
\mathrm{TH}=\left(\mathrm{Ca}^{2+}+\mathrm{Mg}^{2+}\right) \times 100
$$

Potential salinity (PS): [39] proposed the suitability of water for irrigation using potential salinity as stated in eqn. 9 $[37,39]$

$$
\mathrm{Cl}^{-} \sqrt{\mathrm{SO}_{4}^{2-}} \quad(9)
$$

Gibb's plot

For Cations [40]

$$
\mathrm{Na}^{+} /\left(\mathrm{Na}^{+}+\mathrm{Ca}^{2+}\right) \mathrm{meq} / \mathrm{L}
$$

For Anions [40]

$$
\mathrm{Cl}^{-} /\left(\mathrm{Cl}^{-}+\mathrm{HCO}_{3}^{-}\right) \mathrm{meq} / \mathrm{L}
$$

\section{Result and Discussion}

\section{Soluble sodium percentage (SSP)}

[34], stated that when the value of SSP is lower than 50 it implies that the water is suitable for irrigation, while higher values indicates that the water is unsuitable for irrigation. The values of SSP within the study area range from 1.53 to 43.78 with an average value of 22.61 see Figure 3 and Table 4 . The sample locations are considered suitable for irrigation because the SSP value is lower than 50 , the standard limit Table 4. 

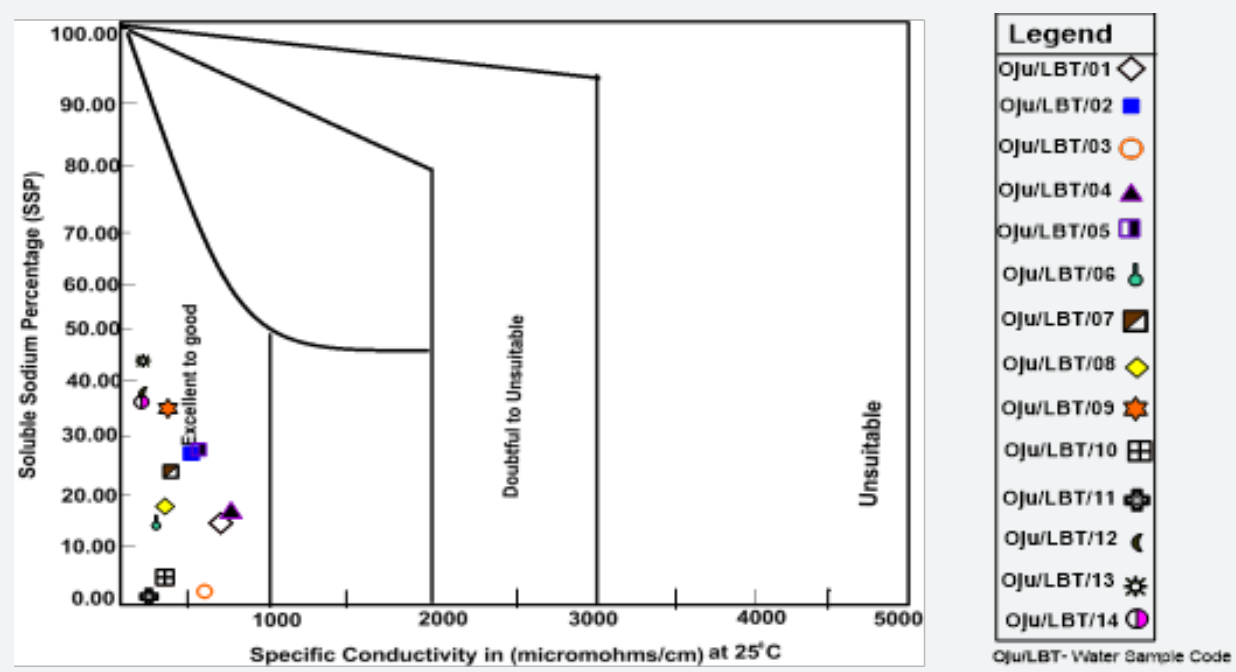

Figure 3: Wilcox Diagram for Water sample of the study Area.

Table 4: Result of Irrigation parameters.

\begin{tabular}{|c|c|c|c|c|c|c|c|c|}
\hline Sample Code & EC & TH & MAR & KR & Na\% & SSP & SAR & PS \\
\hline Oju/LBT/01 & 727 & 252.5 & 32.47 & 0.23 & 23.3 & 18.94 & 0.74 & 0 \\
\hline Oju/LBT/02 & 531 & 213.5 & 25.02 & 0.34 & 38.8 & 27.57 & 1.13 & 0 \\
\hline Oju/LBT/03 & 590 & 225 & 0 & 0.01 & 1.55 & 1.53 & 0.04 & 0 \\
\hline Oju/LBT/04 & 760 & 425.5 & 61.98 & 0.22 & 22.2 & 18.17 & 0.94 & 0 \\
\hline Oju/LBT/05 & 670 & 146 & 0 & 0.38 & 38.69 & 27.9 & 0.94 & 0 \\
\hline Oju/LBT/06 & 318 & 203 & 35.7 & 0.11 & 11.82 & 10.54 & 0.33 & 0 \\
\hline Oju/LBT/07 & 430 & 139.5 & 24.63 & 0.34 & 34.7 & 25.6 & 1.38 & 0 \\
\hline Oju/LBT/08 & 404 & 144 & 6.84 & 0.211 & 21.18 & 17.47 & 0.5 & 0 \\
\hline Oju/LBT/09 & 314 & 205 & 53.9 & 0.56 & 56.82 & 36.2 & 0.29 & 0 \\
\hline Oju/LBT/10 & 362 & 241 & 39.21 & 0.09 & 9.33 & 8.53 & 0.29 & 0 \\
\hline Oju/LBT/11 & 253 & 72 & 6.94 & 0.68 & 68.75 & 4.07 & 0.72 & 0.22 \\
\hline Oju/LBT/12 & 146 & 80 & 6.5 & 0.46 & 46.87 & 38.65 & 0.8 & 0.33 \\
\hline Oju/LBT/13 & 254 & 108.5 & 0 & 0.77 & 77.8 & 43.78 & 1.08 & 0.13 \\
\hline Oju/LBT/14 & 127 & 73 & 0 & 0.6 & 60.2 & 37.6 & 0.73 & 0.47 \\
\hline Minimum & 127 & 72 & 0 & 0.01 & 1.55 & 1.53 & 0.04 & 0 \\
\hline Maximum & 760 & 425.5 & 61.98 & 0.77 & 77.8 & 43.78 & 1.38 & 0.47 \\
\hline Average & 423.31 & 189.12 & 22.19 & 0.36 & 36.96 & 22.61 & 0.7 & 0.1 \\
\hline
\end{tabular}

\section{Magnesium adsorption ratio (MAR)}

[41], stated that calcium and magnesium maintain a state of equilibrium in most waters and that high concentration of magnesium in water is believed to have negative effect on crop yields as the soil becomes more alkaline. [42], further stated that value below 50 is considered the acceptable limit for MAR. The value of MAR within the study area ranges from 0.00 to 61.98 with an average of 22.19 see Table 4 . From results obtained from MAR, sampled locations are considered fit irrigation except Oju/ LBT/04 with value of 61.98, hence his Oju/LBT/04 is considered not fit for irrigation, see Table 4 stated that high concentration of magnesium ions usually affect soil infiltration properties as they are about $50 \%$ bigger than calcium ions and are not very strongly attracted to the clay particles. This causes more water to be adsorbed between the magnesium ions and clay particles thereby reducing the overall soil infiltration rates.

\section{Sodium percentage ( $\mathrm{Na} \%)$}

Sodium percentage is considered as important factor in defining fitness of water for irrigation. It's also an important factor to use in determining sodium hazard [2]. The value of $\mathrm{Na}$ $\%$ within the study area ranges from to 1.15 to $77.80 \%$ with an average value of $36.96 \%$ see Figure 4 and Table 4 . Based on the values of $\mathrm{Na} \%$ from the study area sample location Oju/LBT/01 to 14 is considered fit for irrigation purpose. 

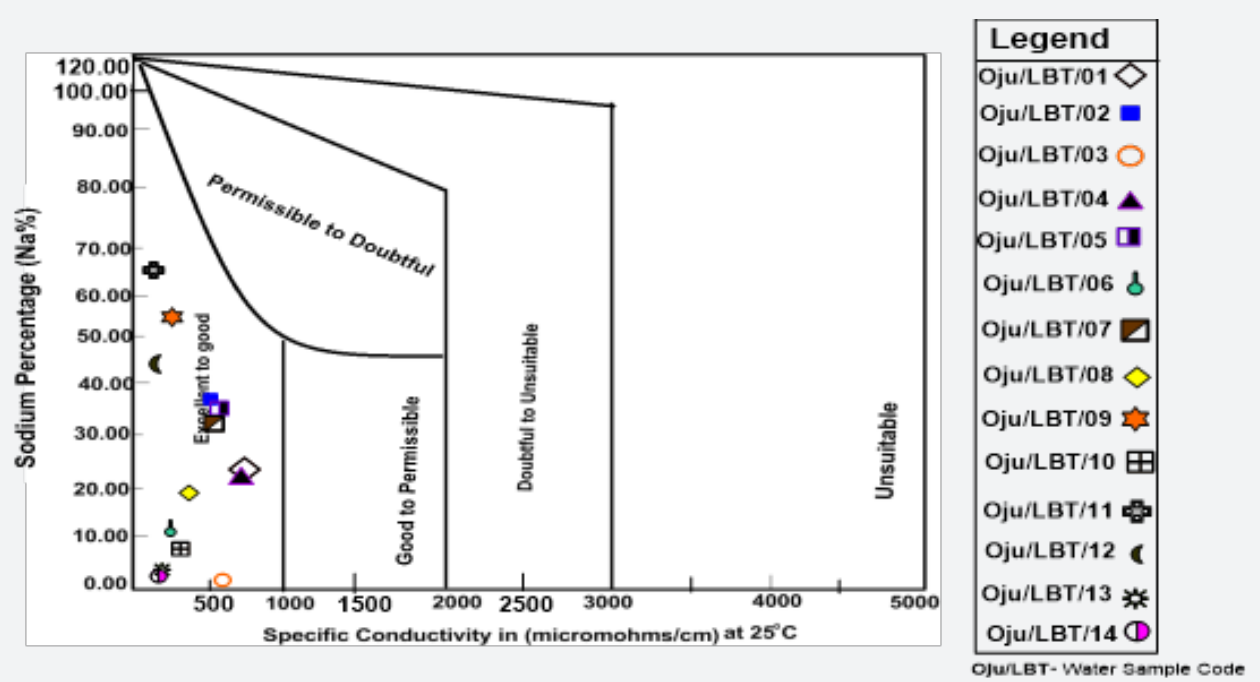

Figure 4: Rating of water samples on the basis of electrical conductivity and sodium percent [43].

\section{Sodium adsorption ratio (SAR)}

$[42,44]$, stated that when the value of SAR rises above 12 to 15 , serious physical soil problems arise, and plants have difficulty absorbing water. SAR also gives information on the comparative concentrations of $\mathrm{Na}^{+}, \mathrm{Ca}^{2+}$ and $\mathrm{Mg}^{2+}$ in the water samples, SAR takes into consideration the fact that the adverse effect of sodium is moderated by the presence of calcium and magnesium ions. The value of SAR within the study area ranges from 0.04 to 1.39 with an average value of 0.70 see Figure 5 and Table 4. From Figure 5 sample location Oju/LBT/12 and 14 falls within the C1 (excellent) category, while 0ju/LBT/02, 03, 05, 06, $07,08,09,10$ and 11 falls within the C2 (good) category and Oju/LBT/01 and 04 falls within the C3 (doubtful) category.

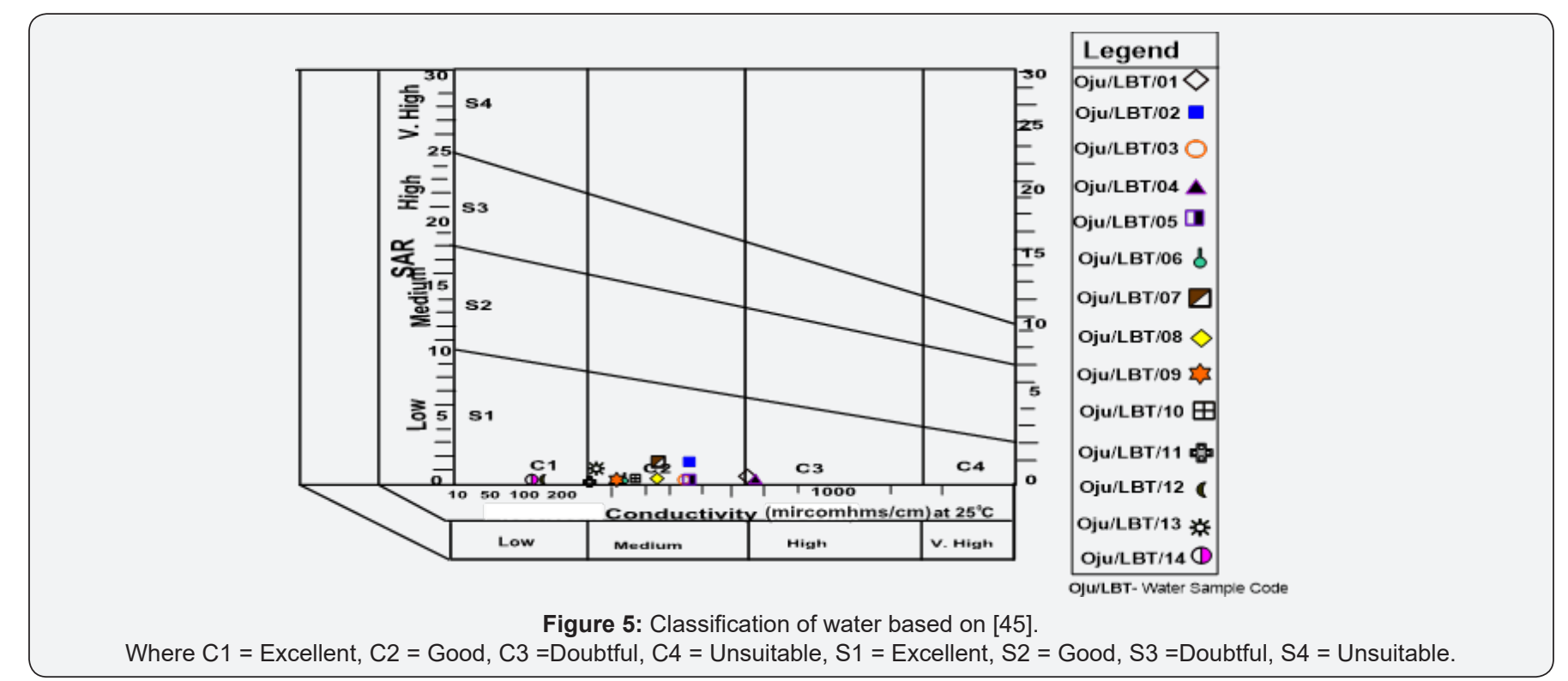

[46] stated that samples with higher salinity are better suited for the soil structure. (Figure 6) shows the impact of irrigation water on the soil properties (infiltration rate in the present case). The low SAR values (average of 0.70 ) see Table 4. [47] stated that SAR of irrigation water represents the tendency of the Na ions to be adsorbed at ion exchange sites within the soil matrix at the expense of $\mathrm{Ca}$ and $\mathrm{Mg}$ and causes the dispersion of soil particles thereby reducing the soil infiltration capacity. However, the reduction in soil permeability brought about by the high SAR values of irrigation water can be counterbalanced by the high salinity values (EC of groundwater). With similar SAR values, samples with higher salinity are better suited for the soil structure [46]. The map of SAR versus EC (Figure 6) shows the impact of irrigation water on the soil properties (infiltration rate in the present case). The low SAR values (average of 0.70 ) and high salinity values (average of $0.41 \mathrm{dS} / \mathrm{m}$ ) results in the water samples falling within slightly to moderate reduction infiltration category. From Figure 5 and 6, groundwater does not have 
any effect on the soil infiltration properties and does not need addition effort such as; addition of calcium to improve the soil property, but the high salinity values can have adverse impact on plant growth. The best option under such conditions would be to grow plants and crops which are high salinity resistant.

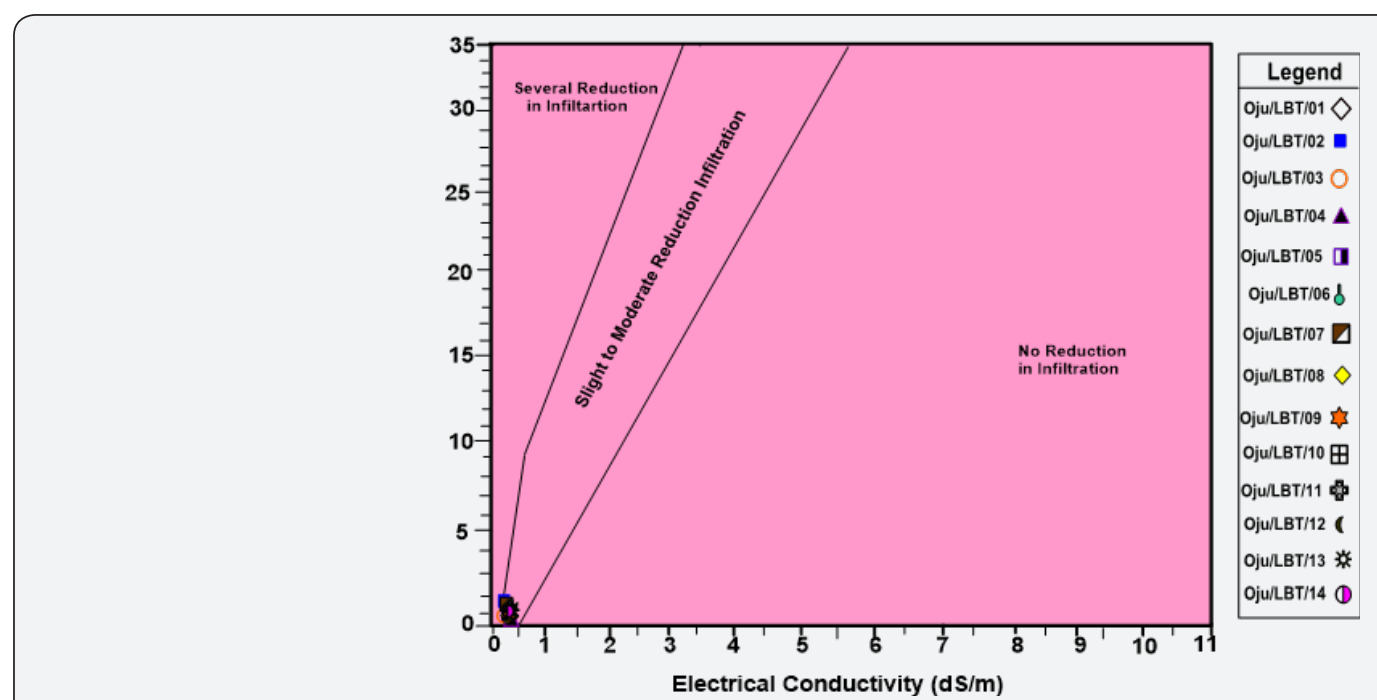

Figure 6: SAR versus EC plot showing the impact of the sampled groundwater on the soil infiltration rates [46].

\section{Kelly ratio (KR)}

[38], stated that when KR is equal to or below 1 it is indicative of good quality water for irrigation whereas a value above 1 is

Table 5: Classification of Water Based on Total Hardness [48].

\begin{tabular}{|c|c|c|c|}
\hline Total Hardness as $\mathrm{CaCO}_{\mathbf{3}} \mathbf{( m g / L )}$ & Water Class & Number of Samples & Percentage of sample (\%) \\
\hline$<75$ & Soft & Oju/LBT/11 and 14 & \\
\hline $75-150$ & Moderately Hard & 0ju/LBT/5,7,8,12 and 13 & \\
\hline $150-300$ & Hard & Oju/LBT/1,2,3,6,9 and 10 & \\
\hline$>300$ & Very Hard & 0ju/LBT $/ 4$ & \\
\hline
\end{tabular}

\section{Total hardness (TH)}

The value of TH ranges from 72.00 to 425.50 with an average value of 189.12 as shown in Table 4 \& 5 Sample location Oju/ LBT $/ 11$ and 14 falls within the soft water category and classified good for irrigation, while sample location Oju/LBT/5, 7, 8, 12 suggestive of unsuitability for agricultural purposes due to alkali hazards. KR value of the study area ranges from 0.01 to 0.77 with an average value of 0.36 see Table 4 . Based on the result for the KR the water is considered fit for irrigation

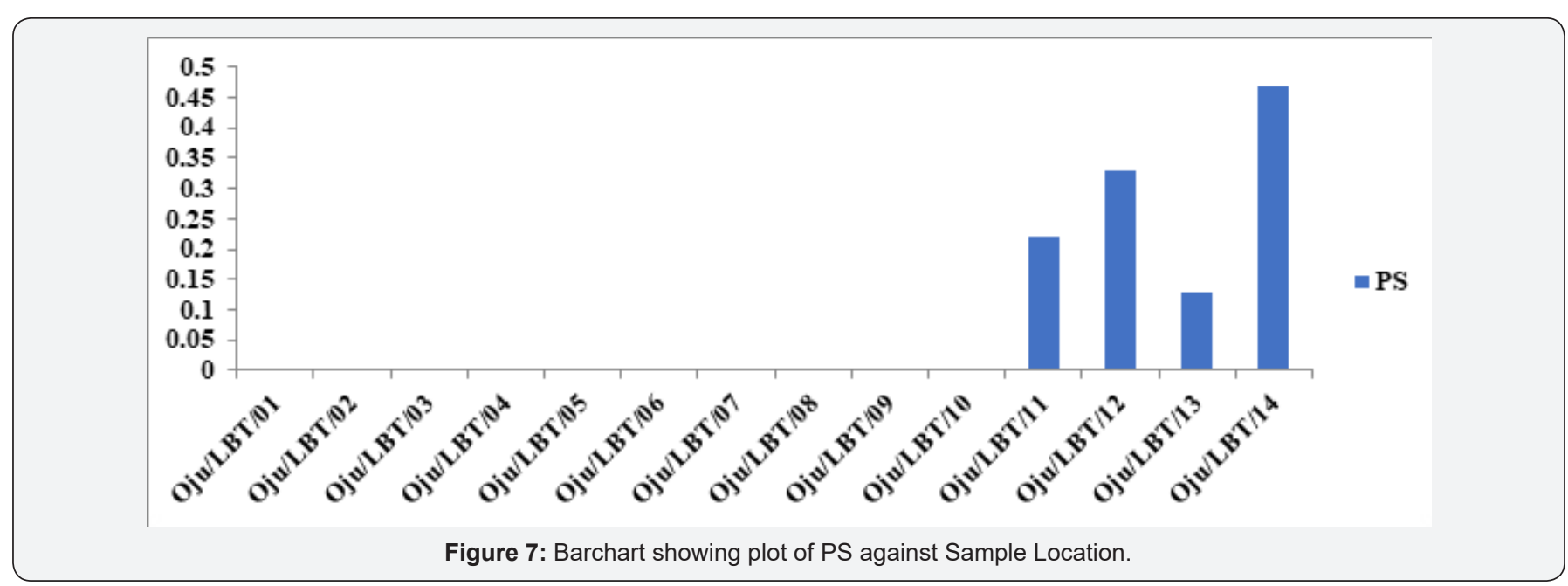




\section{Potential salinity}

Potential salinity of groundwater samples was classified as stated below; excellent to good, value below $5(<5)$, good to injurious value between 5 to 10 (5-10, injurious to unsatisfactory value above $10(>10)$. From detailed interpretation it was observed that, all the samples fall in excellent too good. The value of PS ranges from 0.00 to 0.47 with an average value of 0.10 see Table 4 . Based on this sample location at considered suitable for irrigation (Figure 7).

Table 6: Classification of Groundwater Based on EC.

\begin{tabular}{|c|c|c|}
\hline Salinity Hazard (Class) & EC $\boldsymbol{\mu} / \mathbf{S c m}$ & Sampling Points \\
\hline Excellent(C1) & $<250$ & OJU/LBT/12 and 14 \\
\hline Good (C2) & $250-750$ & OJU/LBT/01, 02, 03, 04, 05, 06, 07, 08, 08, 09, 10, 11, 13 \\
\hline Doubtful(C3) & $750-2250$ & \\
\hline Unsuitable(C4) & $>2,250$ & \\
\hline
\end{tabular}

\section{Electrical conductivity (EC)}

[47], stated that electrical conductivity is considered as important criteria in measuring of salinity hazard to crops as it reflects the TDS in groundwater. EC of the study area ranges from 127 to $760 \mu \mathrm{S} / \mathrm{cm}$ with an average value 423.31 falls within excellent and good category see Table 6 . Based on the value of EC the groundwater is fit for irrigation purpose.

\section{Hydrogeochemical Facies Analysis}

\section{Groundwater evaluation of the study area using Gibbs Plot}

Charactertics of cations and anions and in groundwater display certain physicochemical attribute caused by the groundwater's interaction with soil and rock, while flowing through water bearing formation [49]. Aquifer show attribute of water bodies with various chemical compositions [50]. Such attributes can be linked to hydrochemical facies of groundwater. In most case hydrochemical facies are usually affected by the rocks of the aquifer and the flow of groundwater. The distribution of anions $\left(\mathrm{Cl}^{-}, \mathrm{HCO}_{3}^{-}\right)$and cations $\left(\mathrm{Na}^{+}, \mathrm{Ca}^{2+}\right)$ as well as the TDS were used to plot the Gibbs diagram in other to show the major process that has influence on groundwater within the study area such as; rock dominance, evaporation dominance, precipitation dominance. Gibbs diagram helps in interpreting the influence of hydrogeochemical processes such as; precipitation, rockwater interaction mechanism and evaporation on groundwater chemistry. The reaction between groundwater and aquifer minerals has a major role to play in groundwater quality which is useful to predicate the source of groundwater as shown in Figure 7. Previous research by $[3,50]$ within the Asu River Group of the Lower Benue Trough, has shown that rock dominance is the process in groundwater chemistry. From this study it was observed that rock dominance is the major factor that influence groundwater except for sample location 0ju/LBT/13, while for anions it was observed that rock dominance is the major factor that influence groundwater except for sample location 0ju/ LBT $/ 11,12$ and 14 see Figure 8.

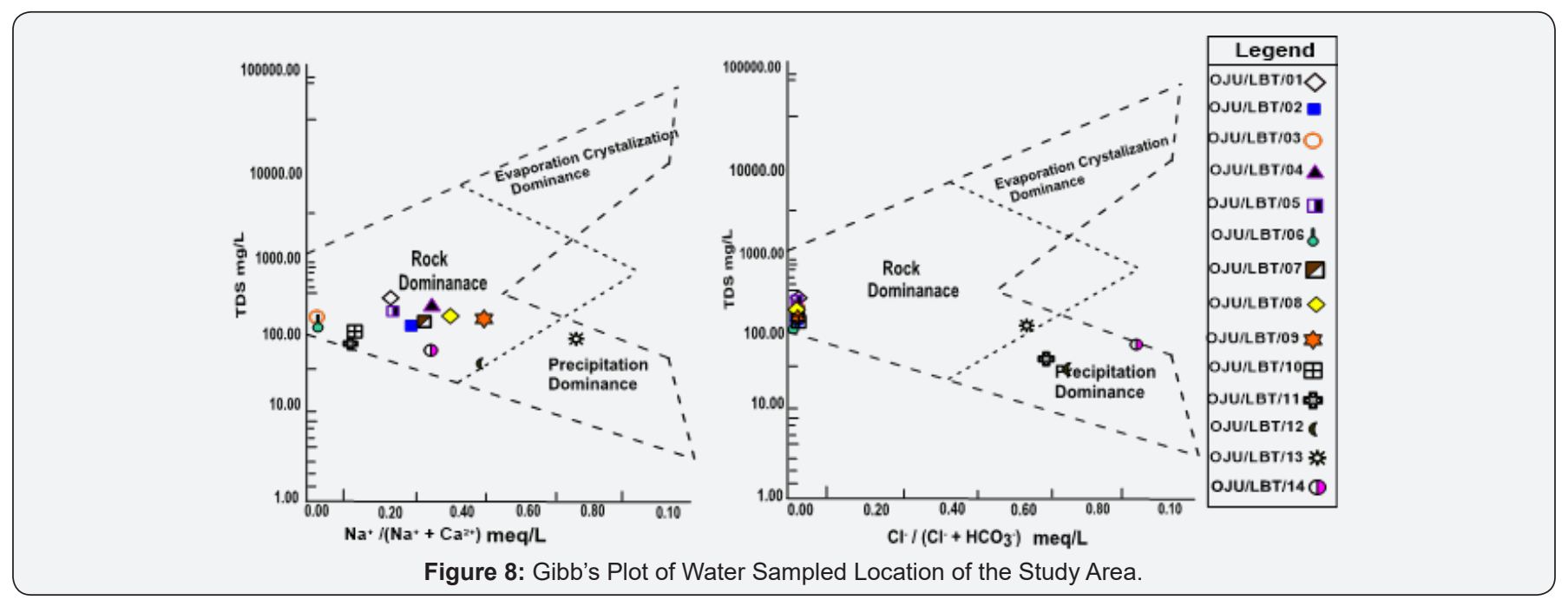

\section{Chadba plots}

Geochemical classification and hydrochemical parameters of groundwater [51] see Figure 9.

a) Alkaline earths exceed alkali metals;

b) alkali metals exceed alkaline earths; c) weak acidic anions exceed strong acidic anions;

d) strong acidic anions exceed weak acidic anions;

e) $\mathrm{Ca}^{2+}-\mathrm{Mg}^{2+}-\mathrm{HCO}_{3}{ }^{-}$water type with temporary hardness;

f) $\mathrm{Ca}^{2+}-\mathrm{Mg}^{2+}-\mathrm{Cl}^{-}$water type with permanent hardness; 
g) $\mathrm{Na}^{+}-\mathrm{Cl}^{-}$water type with salinity problems both in irrigation and domestic uses;

h) $\mathrm{Na}^{+}-\mathrm{HCO}_{3}^{-}$water type causes foaming problems in domestic use.

From Figure 9 Sample locations Oju/LBT/01, 02, 05, 07, 08, 09 and 10 falls within $\mathrm{Ca}^{2+}-\mathrm{Mg}^{2+}-\mathrm{HCO}_{3}{ }^{-}$water type that implies that the listed sample location can be classified as temporary hard water. While sample location 0ju/LBT/03,04, 06, 11, 12, 13 and 14 falls within $\mathrm{Ca}^{2+}-\mathrm{Mg}^{2+}-\mathrm{Cl}^{-}$water type with permanent hardness it could be attributed to presence of high concentration of calcium and magnesium in water sample. [4], used Chadba plot in determine the level of hardness of groundwater within the same geology formation (Asu River Group), from the finding it was observed that groundwater within the Asu River Group fall within the $\mathrm{Ca}^{2+}-\mathrm{Mg}^{2+}-\mathrm{Cl}^{-}$permanent hard category see Figure 9.

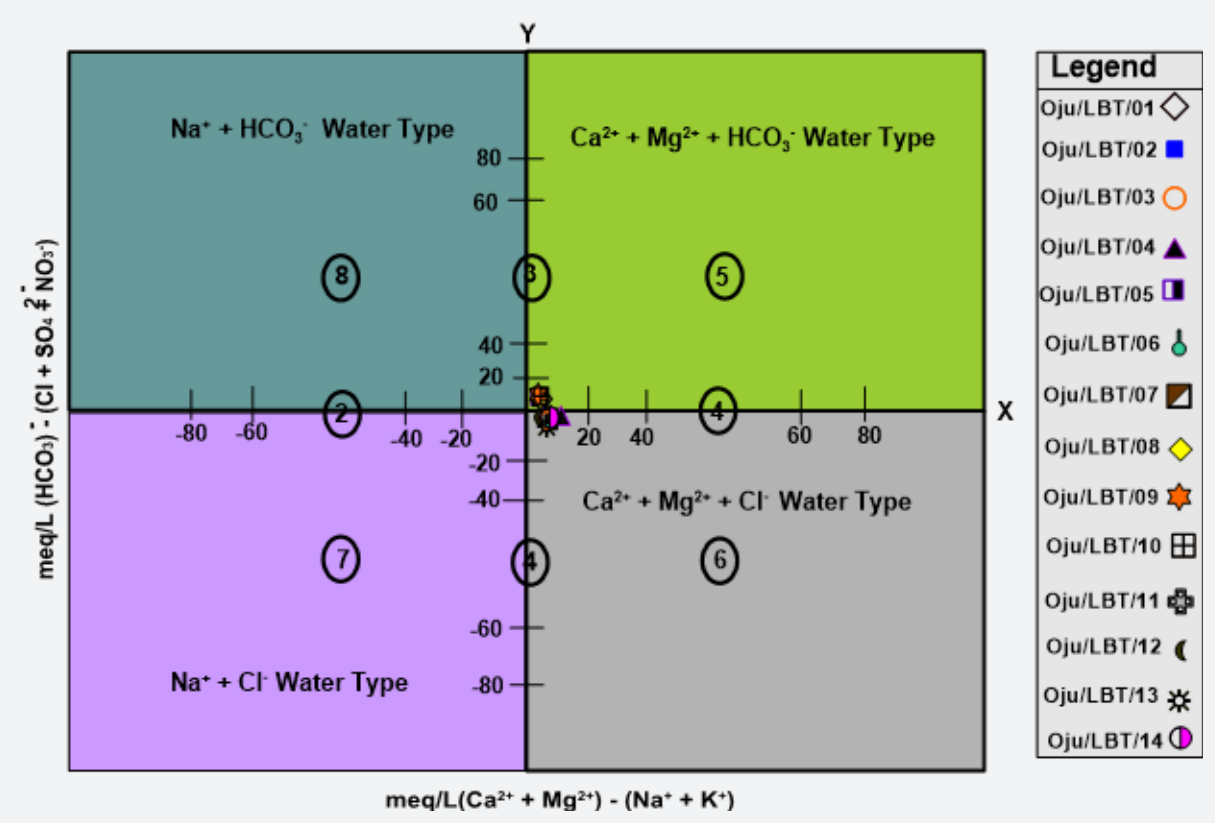

Figure 9: Chadba's Diagram showing Groundwater type of the Study Area.

\section{Ion exchange}

Factor controlling groundwater chemistry was also evaluated using bivariate diagrams such as $\mathrm{Cl}^{-}$versus $\mathrm{Na}^{+}, \mathrm{Mg}^{2+}$ versus $\mathrm{Ca}^{2+}$, $\mathrm{SO}_{4}{ }^{2-}$ versus $\mathrm{Ca}^{2+}$ and $\mathrm{Ca}^{2+}+\mathrm{Mg}^{2+}$ versus $\mathrm{Ca}^{2+}$ as widely used $[49,50]$ see (Figure 10-13) respectively. As for the plot of $\mathrm{Cl}^{-}$ against $\mathrm{Na}^{+}$mineral weathering was observed to have occurred, but ion exchange is dominant process governing groundwater chemistry. Silicate weathering and ion exchange was observed to be major process controlling groundwater chemistry from
$\mathrm{Na}^{+}$against $\mathrm{Cl}^{-}$see Figure 10. From Figure 11 plot of $\mathrm{Mg}^{2+}$ versus $\mathrm{Ca}^{2+}$ showed both sides of $1: 1$ line, this implies that mineral weathering and dissolution, ion exchange and evaporation as the major factor governing groundwater chemistry. While from Figure 12 plot of $\mathrm{SO}_{4}{ }^{2-}$ versus $\mathrm{Ca}^{2+}$, it was observed that the presence of dissolved gypsum in the groundwater is sourced from application of gypsum for the improvement of the soil in the present study area. Figure $13 \mathrm{Ca}^{2+}+\mathrm{Mg}^{2+}$ versus $\mathrm{Ca}^{2+}$ it was observed that large percentage of groundwater falls within reverse ion exchange.

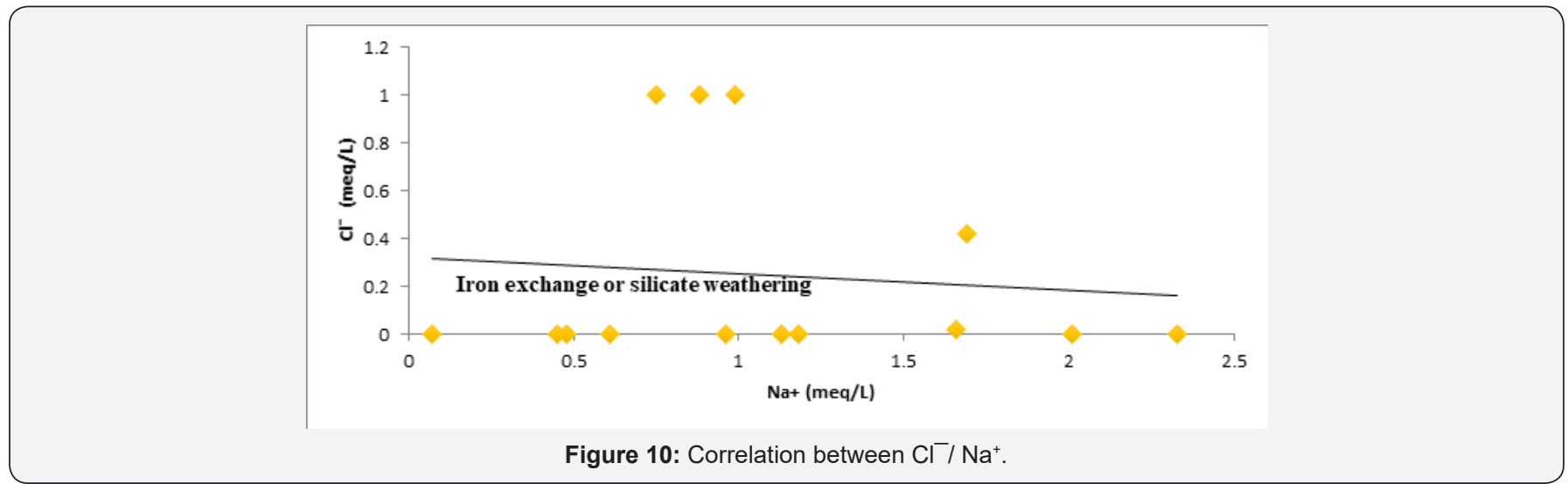




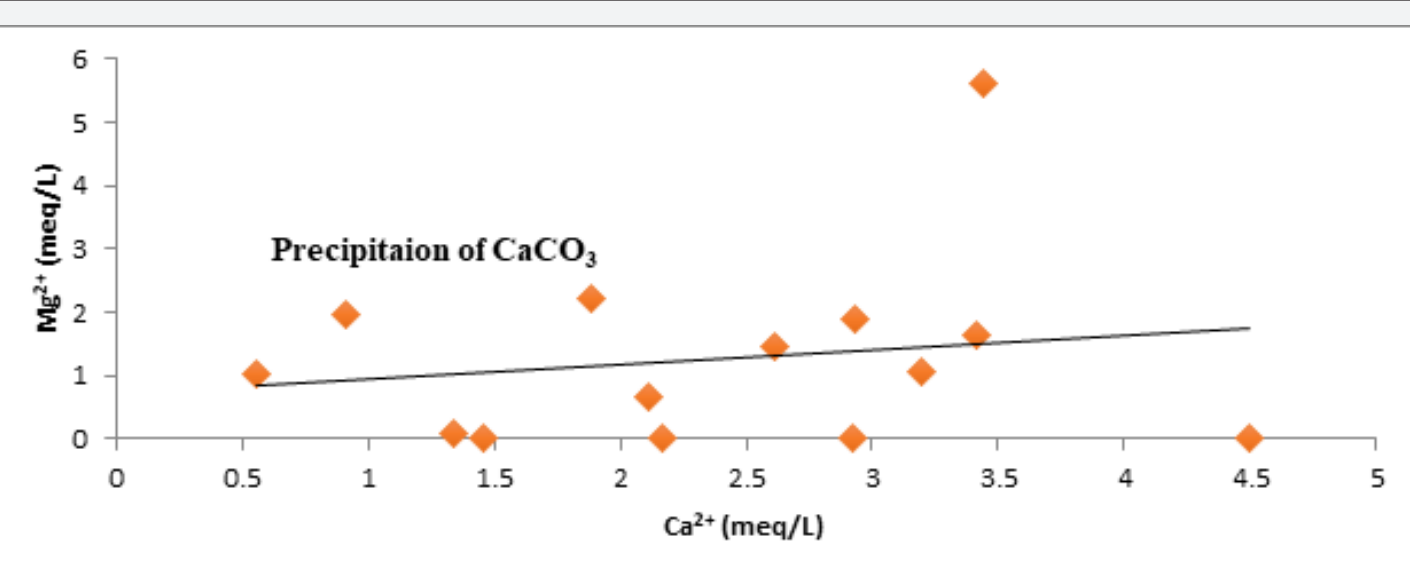

Figure 11: Correlation between $\mathrm{Mg}^{2+} / \mathrm{Ca}^{2+}$.

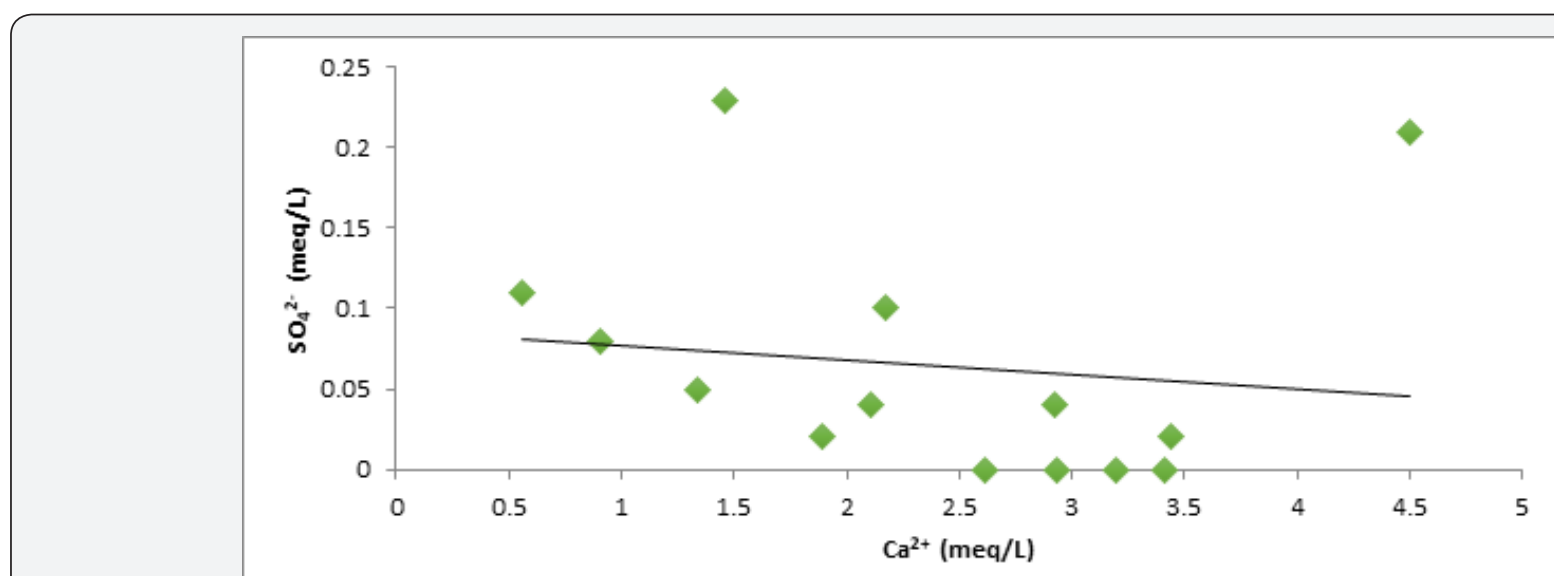

Figure 12: Correlation between $\mathrm{SO}_{4}{ }^{2-} / \mathrm{Ca}^{2+}$.

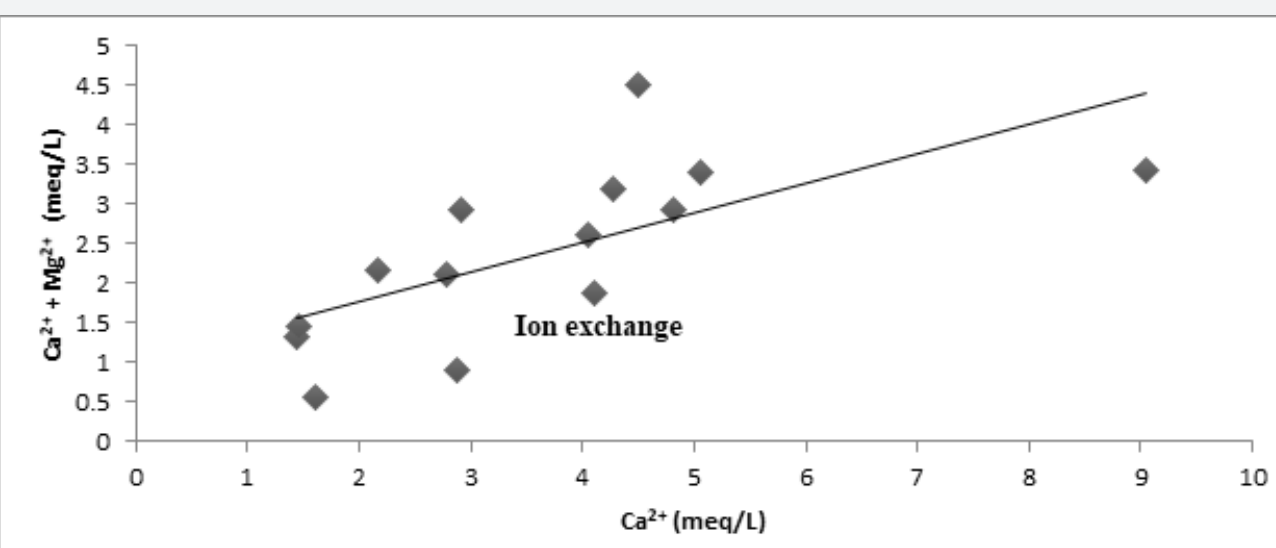

Figure 13: Correlation between $\mathrm{Ca}^{2+}+\mathrm{Mg}^{2+} / \mathrm{Ca}^{2+}$.

\section{Summary and Conclusion}

This research was carried to determine suitability of groundwater from shallow well for irrigation;

\section{Irrigation parameters}

a) From the findings it was observed that SSP 1.53 to 43.78 with an average value of 22.6 , value below 50 is considered suitable for irrigation. Based on this value obtained from SSP is considered suitable for irrigation.

b) Result obtained from MAR were considered suitable for irrigation except 0ju/LBT/04 with value of 61.98, hence his Oju/LBT/04 is considered not fit for irrigation.

c) $\mathrm{Na} \%$ is very paramount when discussing groundwater suitability for irrigation, $\mathrm{Na} \%$ within the study area ranges 
from 1.15 to $77.80 \%$ with an average value of $36.96 \%$, value obtained show that groundwater samples are considered suitable for irrigation based on $\mathrm{Na} \%$.

d) SAR helps give detail information on $\mathrm{Ca}^{2+}+\mathrm{Mg}^{2+}+\mathrm{Na}^{+}$ for irrigation, with value ranging from 0.04 to 1.39 with an average value of $0.70 .0 \mathrm{ju} / \mathrm{LBT} / 12$ and 14 falls within the C1 (excellent) category, while 0ju/LBT/02, 03, 05, 06, 07, 08, 09,10 and 11 falls within the C2 (good) category and 0ju/ LBT/01 and 04 falls within the C3 (doubtful)

e) SAR plotted against electrical conductivity $(\mathrm{dS} / \mathrm{m})$ showed that groundwater samples falling within slightly to moderate reduction infiltration category. One could say groundwater does not have any effect on the soil infiltration properties and does not need addition effort such as; addition of calcium to improve the soil property, but the high salinity values can have adverse impact on plant growth.

f) Values obtained from KR ranges from 0.01 to 0.77 with an average value of 0.36 . As for $\mathrm{KR}$ value $<1$ is considered suitable for irrigation. Based on this value estimated from $\mathrm{KR}$ is fit for irrigation.

g) Hardness of water is an important parameter considered important in determining suitability of water for various use. The value of TH ranges from 72.00 to 425.50 with an average value of 189.12. Sample location 0ju/ LBT/11 and 14, while sample location Oju/LBT/5, 7, 8, 12 and 13 is classified as soft, moderately hard respectively. Sample location Oju/LBT/1, 2, 3, 6, 9 and 10 and lastly sample location Oju/LBT/04 falls within hard to very hard category respectively. This implies that the sampled location is unsuitable for irrigation.

h) The value of PS ranges from 0.00 to 0.47 with an average value of 0.10 , hence is considered suitable for irrigation.

i) Electrical Conductivity value of the study area ranges from 127 to $760 \mu \mathrm{S} / \mathrm{cm}$ with an average value $423.31 \mu \mathrm{S} / \mathrm{cm}$, the value falls within excellent to good category, based on this the sample location are considered suitable for irrigation.

\section{Hydrogeochemical Facies}

\section{Gibbs plot}

Gibbs Plot, it was observed that rock dominance is the major factor controlling groundwater chemistry within except for Oju/ LBT/11, 12 and 14 where precipitation dominance has influence on groundwater.

\section{Chadba Plot}

Sample location Oju/LBT/03,04, 06, 11, 12, 13 and 14 falls within $\mathrm{Ca}^{2+}-\mathrm{Mg}^{2+}-\mathrm{Cl}^{-}$water type with permanent hardness it could be attributed to presence of high concentration of calcium and magnesium in water sample. While sample locations Oju/ LBT/01, 02, 05, 07, 08, 09 and 10 falls within $\mathrm{Ca}^{2+}-\mathrm{Mg}^{2+}-\mathrm{HCO}_{3}^{-}$ water type that implies that the listed sample location can be classified as temporary hard water this could be attributed presence of high concentration of magnesium and calcium.

\section{Ion exchange}

From findings it was observed that weathering is the major processing influence groundwater quality in the study area.

\section{References}

1. Goni IB, Edet AE, Olasehinde PI, Adelana SMA, Vrbka P, et al. (2008) An overview of the geology and hydrogeology of Nigeria. IAH - Selected Papers on Hydrogeology.

2. Eyankware MO, Obasi PN, Akakuru OC (2016) Use of Hydrochemical Approach in Evaluation of Water Quality around the Vicinity of Mkpuma Ekwaoku Mining District, Ebonyi State, SE. Nigeria for Irrigation Purpose. Indian Journal of Science 23(88): 881-895.

3. Eyankware MO (2016) Hydrochemical Apprasial of Groundwater for Irrigation Purpose: A Case Study of Ekaeru Inyimagu and Its Adjoining Area, Ebonyi State, Nigeria. Indian Journal of Science 23(88): 924-994.

4. Eyankware MO (2017) Hydrogeochemical Evaluation of Groundwater for Irrigation Purposes in Mining Areas of Umuoghara Near, Abakaliki, SE. Nigeria. Science and Technology 3(9): 1-19.

5. Eyankware MO, Nnajieze VS, Aleke CG (2018a) Geochemical Assessment of Water Quality for Irrigation Purpose, in Abandoned Limestone Quarry pit at Nkalagu area, Southern Benue Trough Nigeria. Environ Earth Science 77: 66

6. Ezeh VO, Eyankware MO, Irabor OO, Nnabo PN (2016) Hydrochemical Evaluation of Water Resources in Umuoghara and its environs, near Abakaliki, South Eastern Nigeria. International Journal of Science and Healthcare Research 1(2): 23-31.

7. Islam MJ, Hakim MA, Hanafi MM, Abdul SJ, Sharmin A, et al. (2013) Hydrogeochemical quality and suitability studies of groundwater in northern Bangladesh. Journal of Environmental Biology 35(4): 765 -779 .

8. Sreenivasa A, Ajaykumar NA (2015) Water Quality Assessment for Drinking and Irrigational Suitability of Galgibagh River Sub-basin (GRSB), Goa. International Journal of Scientific Research in Science, Engineering and Technology 1(6): 327-331.

9. Jain CK, Bandyopadhyay A, Bhadra A (2012) Assessment of Ground Water Quality for Irrigation Purpose, District Nainital, Uttarakhand, India. Journal of Indian Water Resources Society 32(3-4): 8-14.

10. Obasi PN, Eyankware MO, Akudinobi BBE, Nweke MO (2015) Hydrochemical Investigation of WaterResources around Mkpuma Ekwaoku Mining District, Ebonyi State Southeastern Nigeria. African Journal of GeoScience Research 3(3): 01-07.

11. Balogun YO (2005) Senior Secondary school Atlas. ( $\left.2^{\text {nd }} E d n\right)$ Longman, pp. 161.

12. Cocker MD (1995) Geochemistry and hydrochemistry of the Oconee River Basin. In: Hatcher KJ (Ed.), Proceedings of 1995. Georgia water resources conference held on the 11-12 April, University of Georgia, pp. 67-70.

13. Pazand K, Gbanbari Y, Aghavali B, Hezarkhani A (2011) Groundwater Geochemistry in the middle Meshkinshahr basin of Ardabil province in Iran. Environ Earth Sci 1131-8.

14. Nwachukwu SO (1972) The Tectonic Evolution of the Southern Portion of the Benue Trough, Nigeria. Geological Magazine 109(05): 411-419.

15. Cratchley CR, Jones GP (1965) An Interpretation of the Geology and Gravity Anomalities of Benue valley, Nigeria: Oversea Geological survey Geophysics, Paper No.1, 29. 
16. Burke K, Dessavaige TFG, Whiteman AJ (1971) The Opening of Gulf of Guinea and Geological History of the Benue Depression and Niger Delta. Nature Physics Sci 233: 51-55.

17. Grant NK (1971) South Atlantic, Benue Trough and Gulf of Guinea Cretaceous Triple Junction. Bull Geo Soc Am 82(8): 2295-2298.

18. Benkhelil J (1989) The origin and evolution of the Cretaceous Benue Trough Nigeria. Journal of African Earth Sciences (and the Middle East) 8(2-4): 251-282.

19. Obiora SC, Umeji AC (2004) Petrographic Evidence for Regional Burial Metamorphism of the Sedimentary Rocks in the Lower Benue Rift. J African Journal of Earth Science 38(3): 269-277.

20. Simpson A (1954) The Nigerian Coalfield. The geology of parts of Onitsha, Owerri and Benue Provinces. Bulletin Geological Survey Nigeria 24(8): 85.

21. Reyment RA (1965) Aspects of the Geology of Nigeria: The Stratigraphy of the Cretaceous and Cenozoic Deposits. Ibadan University.

22. Nwajide CS (2013) Geology of Nigeria's Sedimentary Basin. CSS Bookshops Ltd Lagos, pp. 565.

23. Kogbe CA (1976) Geology of Nigeria. Elizabethan Publishing Company.

24. Bain ADN (1924) The Nigerian coalfields section 1. Enugu area. Bull Geol Surv Nig 6: 106-120.

25. Offodile ME (1976) The Geology of the Middle Benue, Nigeria. Paleontologiska inst, Uppsala universitet.

26. Nwachukwu SO (1972) The Tectonic Evolution of the the southern portion of the Benue Trough, Nigeria. Geological Magazine 109(05): 411-419.

27. Amajor LC (1985) The Cenomanian Hiatus in the Southern Benue Trough, Nigeria. Geological Magazine 122(01): 39-50.

28. Nwajide CS (1990) Cretaceous Sedimentation and Paleogeography of the Central Benue Trough. In: Ofoegbu CO (Ed.), The Benue Trough structure and Evolution International Monograph Series, Braunschweig, pp. 19-38.

29. APHA (2012) Standard methods for the examination of water and wastewater. (22 ${ }^{\text {nd }}$ edn), American Public Health Association.

30. Hounslaw W (1995) Water Quality Data: Analysis and Interpretation. CRC Press, Boca Raton, pp. 71-127.

31. Domenico PA, Schwartz FW (1990) Physical and Chemical hydrology, John Wiley and sons, New York, 410.

32. Schwartz FW, Domenico PA (1990) Physical and Chemical hydrology, John Wiley and sons, New York, 410.

33. Richards LA (1969) Diagnosis and improvement of saline and alkali soils. In: United States Salinity Laboratory Staff Agricultural Handbook No. 60. The United States Government Printing Office, Washington DC.
34. Todd DK (1980) Groundwater Hydrology, 2nd ed. John Wiley and Sons, Inc. New York, p. 516.

35. Raghunath HM (1987) Groundwater, 2nd Ed. Wiley Eastern Ltd. New Delhi, India, pp. 344-369.

36. Eaton FM (1950) Significance of carbonates in irrigation waters. Soil Sci 69: 123-133.

37. Doneen LD (1964) Water quality for agriculture. Department of irrigation, University of California, Davis, pp. 48.

38. Kelly WP (1963) Use of Saline Irrigation Water. Soil Sci 95(4): 355-359.

39. Doneen LD (1954) Salinization of soil by salt in the irrigation water. Amer Geophys Union Trans 35(6): 943-950.

40. Gibbs RJ (1970) Mechanisms controlling world water chemistry. Science 170(3962): 1088-1090.

41. Joshi DM, Kumar A, Agrawal N (2009) Assessment of irrigation water quality of River Ganga in Haridwar District India. J chem 2(2): 285-292.

42. Munshower FF (1994) Practical Handbook of Disturbed Land Revegetation. Lewis Publishers, Boca Raton, Florida.

43. Wilcox LV (1955) Classification and use of irrigation water," USDA, Circular, Washington, DC, USA, pp. 969.

44. Talabi AO, Afolagboye OL, Tijani MN, Aladejana JA, Ogund (2014) Hydrogeochemistry of Some Selected Springs' Waters in Ekit Basement Complex Area, Southwestern Nigeria 3(2): 19-30. 45.

45. U.S. Salinity Lab (1954) Saline and Alkali Soils - Diagnosis and Improvement of U.S. Salinity Laboratory. Agriculture Handbook No.60, Washington. 46 .

46. Hanson B, Grattan SR, Fulton A (1999) Agricultural Salinity and Drainage. University of California Irrigation Program. Davis: University of California.

47. Sawid FA, Issa AA (2015) Assessment of groundwater quality for drinking and irrigation purposes, Martubah plain, eastern. Libya Transactions on Ecology and The Environment 196: 311-325.

48. Sawyer CN, McCarty PL (1967) Chemistry for sanitary engineers. $\left(2^{\text {nd }}\right.$ edn), McGraw-Hill, New York, pp.518.

49. Subba Rao N, Surya Rao P (2010) Major ion chemistry of Groundwater in a river basin: a study from India. Environ Earth Sci 61(4): 757-775.

50. Eyankware MO, Ogwah C, Okeke GC (2018b) Geochemical Evaluation of Groundwater Origin Using Source Rock Deduction and Hydrochemical Facies at Umuoghara Mining Area, Lower Benue Trough, SE Nigeria. International Research Journal of Earth Science 6(10): 1-11.

51. Chadha DK (1999) A proposed new diagram for geochemical classification of natural waters and interpretation of chemical data. Hydrogeol J 7(5): 431-439. 
CC (P) This work is licensed under Creative
Your next submission with Juniper Publishers will reach you the below assets

- Quality Editorial service

- Swift Peer Review

- Reprints availability

- E-prints Service

- Manuscript Podcast for convenient understanding

- Global attainment for your research

- Manuscript accessibility in different formats ( Pdf, E-pub, Full Text, Audio)

- Unceasing customer service

Track the below URL for one-step submission https://juniperpublishers.com/online-submission.php 